\title{
CONTROLE E AQUISIÇÃO CONJUGADA DE DADOS DE ESPECTRÔMETRO BETA(-) PARA RÁDIO CARBONO E TRÍTIO DO IG-USP
}

\author{
K.Sato 1 \\ A.M.Geyh ${ }^{2}$ \\ K. Kawashita ${ }^{1}$
}

\section{INTRODUÇÃo}

Hardware e software para micro computador Apple especialmente desenvolvidos para dois contadores proporcionais doados pela Volkswagen Stiftumgwerk e utilizados na deteção de pulsos devidas a desintegração de beta(-) de C-14 e H-3 em anti-coincidência com pulsos de detetores externos acha-se em pleno funcionamento.

O trabalho global foi iniciado durante o estágio de um dos autores (K.Sato) em Hannover junto ao laboratório de rádio carbono e trítio de Niedersaschisches Landesamt fur Bodenforshung com quem mantemos convênio de pesquisa bilateral (USP/NLB), e no qual contamos com o assesoramento do Sr. Schults ao qual agradecemos.

\section{HARDWARE}

O hardware para a aquisição, simultânea ou não, dos dados provenientes até 18 canais (9 canais para C-14 e 9 para $\mathrm{H}-3$ ) acha-se ilustrada na forma de diagrama de bloco (Fig.1).

A operação de todo o conjunto pode ser resumida conforme segue:

.os pulsos captados pelos detetores internos (câmaras proporcionais) e externos ou guard (coroa de contadores para trítio e fotomultiplicadora com cristal de Nal (TI) de geometria especial) são pré-amplificados;

.os sinais pré-amplificados podem ser qualificados em:

a) Guard - acusados pelo contadores externos e devida à radiação externa

ou ambiental;

\footnotetext{
1Departamento de Geologia Geral, Instituto de Geociências, USP.

${ }^{2}$ Niedersachsisches Landesant for Bodenforschung, Hannover, Alemanha.
} 
b) coincidente - captados simultâneamente pelo detetores interno e externo e discriminados em dois níveis distintos de energia para emissões beta (-) devidas a $\mathrm{C}-14$ e $\mathrm{H}-3$ conforme quadro abaixo:

$$
\begin{array}{lll} 
& \text { coincidente } & \text { sobre-coincidente } \\
\text { trítio } & >2 \mathrm{mV} e<53 \mathrm{mV} & >60 \mathrm{mV} \\
\text { carbono } & >4 \mathrm{mV} \mathrm{e}<40 \mathrm{mV} & >45 \mathrm{mV}
\end{array}
$$

c) anti-coincidente - captados somente pelo detetor interno, e em anticoicidência com detetor externo. São discriminados em 6 niveis de energia conforme quadro abaixo:

$$
\begin{aligned}
& \mathrm{H}-3>2>5>10.5>21>53>60(\mathrm{mV}) \\
& \mathrm{C}-14>4>5>10>25 . .>45>50(\mathrm{mV})
\end{aligned}
$$

.os pulsos discriminados, conforme acima, são contados em 9 canais independentes utilizando TTL74590;

.os diversos canais podem ser controlados pelo multiplexador TTL 74154 e as transmissões dos dados ao micro Apple são efetuados via buffer $\mathrm{Cl} 74245$. Este Data Bus Buffer de funciomento bidirecional, está atuando apenas unidirecionalmente no modo Read. No modo Write o endereçamento dos controles Reset, Start e Stop dos contadores de cada canal são executados de forma independente através do $\mathrm{Cl} 7475$ (latche).

\section{SOFTWARE}

O software aplicativo está esquematizado na forma de diagrama de blocos (Fig. 2).

.Através de uma das 3 opções, os contadores para radiocarbono e trítio podem ser acionados independente ou simultâneamente. Cada equipamento contém 9 contadores de pulsos distintos segundo níveis de energias que são pré-ajustados.

.O início e re-início para entrada de novas intruções para um dos dois contadores pode ser efetuado através do comando CTRLC.

.Os tempos requeridos variam conforme os níveis de atividades de amostras e das precisões requeridas. No caso do trítio pode necessitar alguns dias, enquanto que para rádiocarbono pode ser desde um dia até várias semanas. Falhas de energia podem invibiliazar períodos tão longos de contagen. Por inexistência de gerador No Break, as contagens são acumuladas em blocos de 100 minutos e armazenados no disquete para posteriores tratamentos matemáticos.

.Para o controle de tempo de contagem é utilizado o relógio interno do próprio Apple, o que é efetuado através do FOR - NEXT.

.Os comandos de Reset, Start e Stop são efetuados pelo comandos POKEs, enquanto que as aquisições de dados pelo comandos PEEKs. 


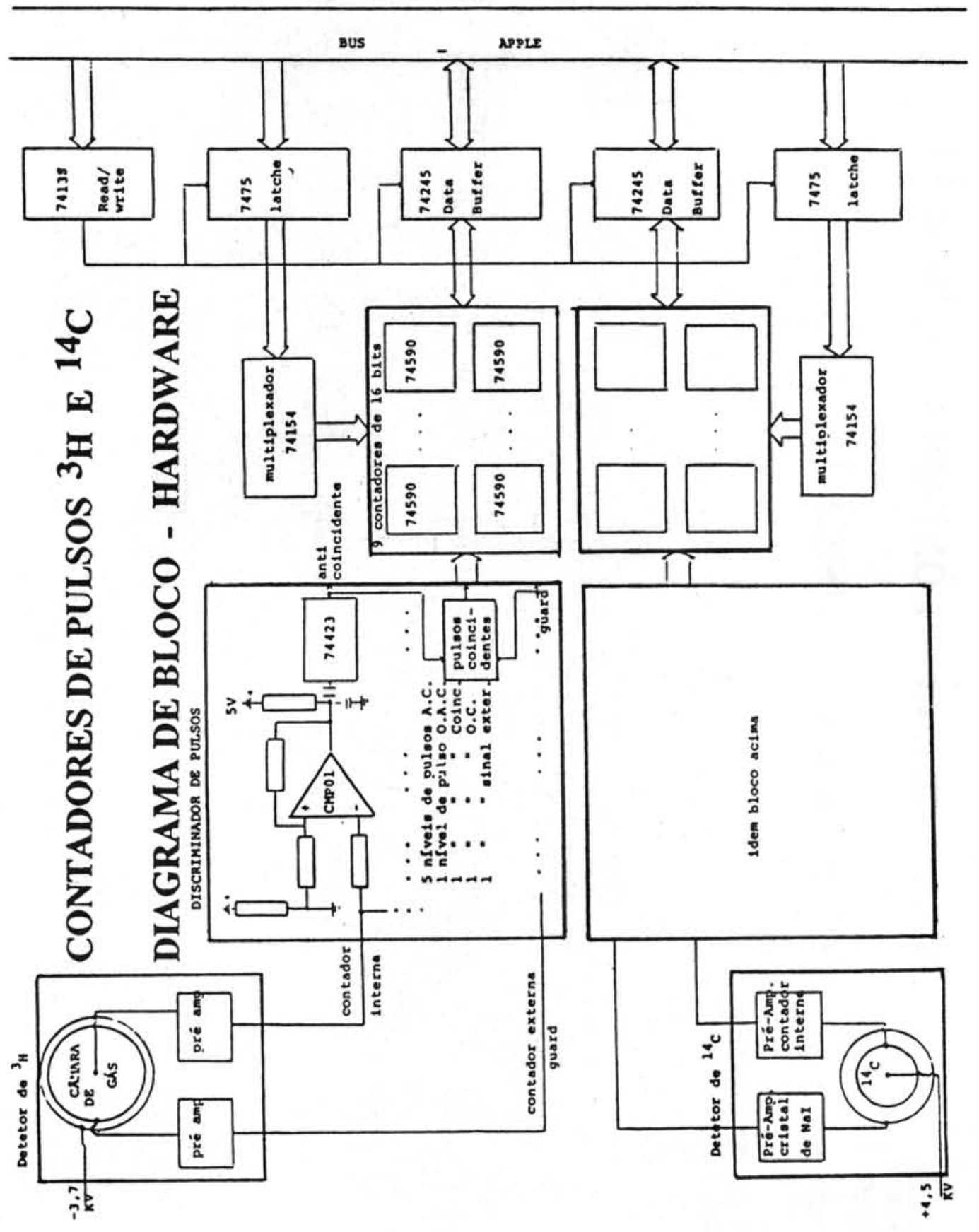




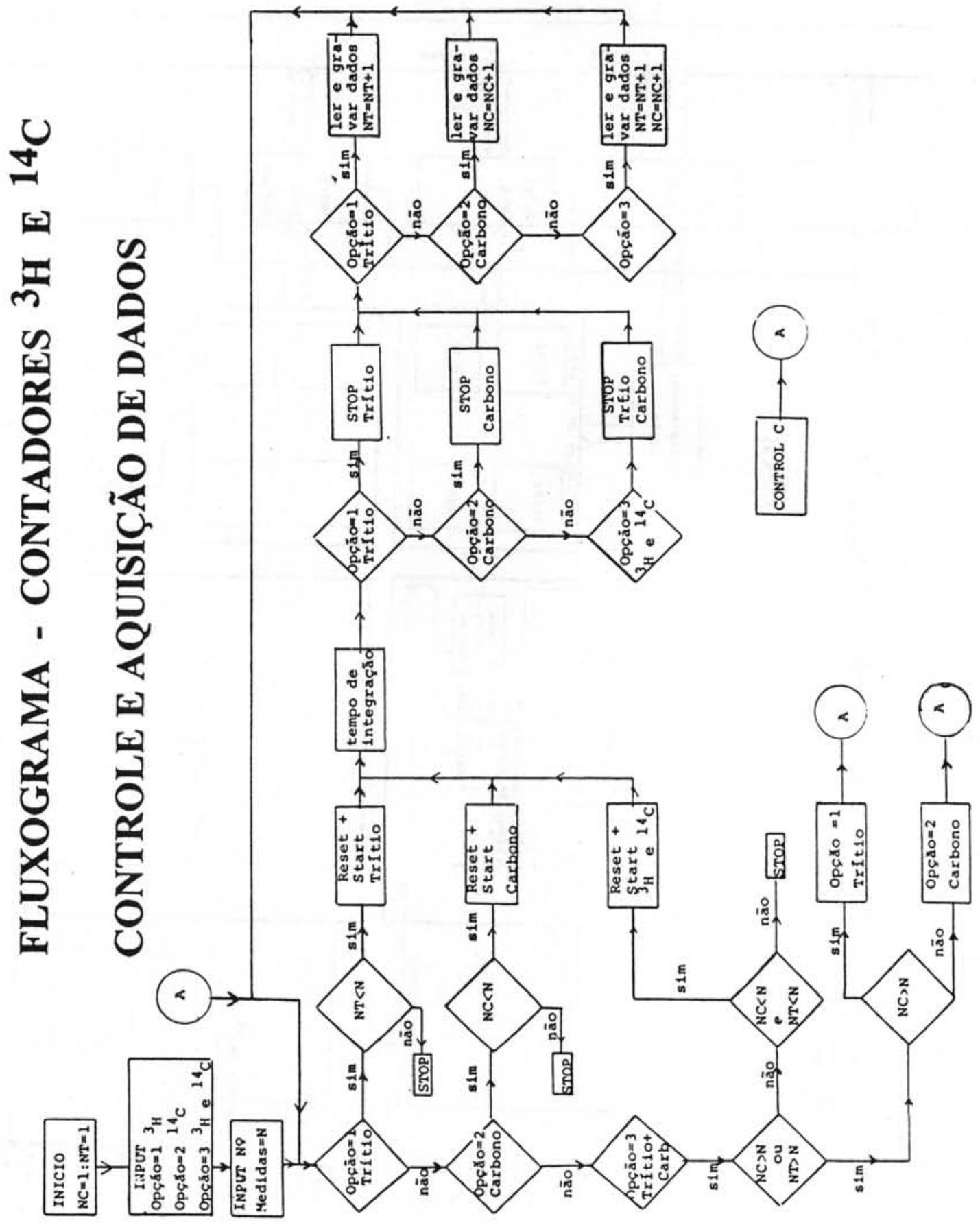

